\title{
EFEKTIVITAS TERAPI ICE MASSAGE DAN BACK MASSAGE TERHADAP PERUBAHAN INTENSITAS NYERI PADA PASIENLOW BACK PAINDI RUMAH SAKIT GRANDMED LUBUK PAKAM TAHUN 2020
}

\author{
Kardina Hayati ${ }^{1}$, Tati Devi ${ }^{2}$ \\ 1,2 Institut Kesehatan MEDISTRA LubukPakam \\ Jl. Sudirman No 38 LubukPakamKab.DeliSerdang, Sumatera Utara. \\ e-mail: kardinahayati@medistra.ac.id 1
}

DOI : https://doi.org/10.35451/jkf.v2i2.385

\begin{abstract}
Low back pain is one of the causes of musculoskeletal due to poor activity the emergence of aches, rheumatic pain, aching. Pain management can be overcome by non-pharmacological therapy using back and ice massage. The purpose of this study was to looked for effectiveness of message ice therapy and back massage for changes in pain intensity in low back pain patients at GrandmedLubukPakam Hospital. The research method used was preexperiment with a one group pre-test post test design model, the sample consisted of 30 samples taken by purposive sampling. Analysis of the data used is the Paired Sample t-test. The results showed there is an effectiveness of Ice Massage therapy and Back Massage therapy at the level of pain intensity in Low Back Pain patients. The result Based on the results of the statistical test, the value of $p=0,001 \leq a 0,05$ for each therapy.Statistical effectiveness test was performed between ice massage and back massage therapy on the level of pain intensity was the most effective back massage therapy to reduce pain intensity with a value of 3,600 and SD (0.516). Cold compresses have several advantages including causing local analgesic effects, reducing inflammation, increasing the threshold for pain receptors and then reducing pain. Back massage can cause a mechanism to close the pain impulse while rubbing the patient's roller gently. The resulting message will stimulate the mechanoreceptor. Expected ice massage and back therapy can be an alternative nursing action in dealing with pain in low back pain patients.
\end{abstract}

Keywords: ice and back massage, low back pain 


\section{PENDAHULUAN}

Memasuki era globalisasi aktifitas semakin banyak dan kegiatan yang dilakukan ternyata sering membawa dampak pada tingginya angka kejadian penyakit tertentu salah satunya yaitu keluhan nyeri punggung bawah (Fadhli, 2014). World Health Organization (WHO) juga menyatakan bahwa di negaraindustritiap tahun tercatat $2-5$ $\%$ mengalami Nyeri PunggungBawah (NPB). Kemudian National Safety Council melaporkan bahwa sakit akibat kerja dengan frekuensi kejadian yang paling tinggi adalah sakit/nyeri pada punggung bawah, yaitu $22 \%$ dari 1.700.000 kasus (Tatilu, 2014).

Survei yang pernah dilakukan pada 1.000 pekerja kantor berusia 18 atau lebih di seluruh Amerika Serikat, 2 dari 3 pekerja kantor merasa sakit dan nyeri pada tubuhnya dalam 6 bulan terakhir. American Osteopathic Association (AOA) dalam survei menunjukkan, bahwa dalam 30 hari terakhir sekitar $62 \%$ responden merasakan nyeri di punggung bawah, $53 \%$ di leher, 38\% di bahu, 33\% di pergelangan tangan, dan $31 \%$ di punggung bagian atas (American Osteopathic Association, 2013).

Kelompok Studi Nyeri (Pokdi Nyeri) Persatuan Dokter Spesialis Saraf Indonesia (PERDOSSI) melakukan penelitian pada bulan Mei 2012 di 14 rumah sakit pendidikan, dengan hasil menunjukkan bahwa jumlah penderita nyeri sebanyak 4456 orang $(25 \%$ dari total kunjungan), 1598 orang (35,86\%) merupakan penderita nyeri kepala dan 819 orang $(18,37 \%)$ adalah penderita LBP (Meliala, 2015). Sementara di Indonesia walaupun data epidemiologic mengenai LBP belum ada namun diperkirakan $40 \%$ penduduk Jawa Tengah berusia antara 65 tahun pernah menderita nyeri punggung dan prevalensinya pada laki-laki $18,2 \%$ dan padaperempuan $13,6 \%$ (Meliawan, 2015).

Angka kejadian nyeri punggung bawah atau dalam Bahasa Inggris Disebut Low Back Pain (LBP), hamper sama pada semua populasi baik di negara maju maupun di Negara berkembang (Shocker, 2018). Angka kejadian LBP di Amerika Serikatmencapai sekitar $5 \%$ pada orang dewasa. Kurang lebih 60\% $80 \%$ individu pernah mengalami nyeri punggung dalam hidupnya. Puncak usia penderita LBP adalah pada usia 45 - 60 tahun. Pada penderita dewasa tua, LBP dapat mengganggu aktivitas sehari-hari pada $40 \%$ penderita, dan gangguan tidur pada $20 \%$ penderita. Sebagian besar $75 \%$ penderita akan mencari pertolongan medis, dan $25 \%$ diantaranya perlu dirawat inap untuk evaluasi lebih lanjut (Widiyaningsih, 2015).

Berdasarkan beberapa teori dan riset di atas tentang dampak low back pain, maka perlu dilakukan upaya untuk mengurangi nyeri. Mengurangi nyeri dapat dilakukan menggunakan terapi farmakologis ataupun menggunakan terapi non farmakologis. Metodecryotherapy yang dapat digunakan yaitu ice massage. Penanganan dengan menggunakan ice massage dilihat dari proses trauma atau cedera pada jaringanlunak. Aplikasi dengan menggunakan ice massage dapat memberikan perubahan pada kulit, jaringan subkutan, intramuscular dan suhu pada persendian (Cheung et al, 2013). Back Massage adalah salah satu teknik memberikan tindakan pijat pada punggung dengan usapan secara perlahan. Usapan dengan minyak zaitun memberikan sensasi hangat dengan mengakibatkan dilatasi pada pembuluh darah local (Kusyati, 2016). 
Berdasarkan hasil survey pendahuluan yang dilakukan di Rumah Sakit Grandmed Lubuk Pakam, didapatkan data pasien pada tahun 2019 yang mengalami Low Back Pain periode Januari - September terdapat 59 pasien yang mengalami Low Back Pain. Dan dari jumlah pasien yang mengalami low back pain Permasalahan yang paling sering terjadi yaitu yang berhubungan dengan rasa nyeri. Hal ini dapat diamati atau diobservasi berdasarkan keadaan pasien yang masih mengalami Nyeri dibagian punggung bawah, meringiskesakitan, gelisah, susah tidur dan cemas.

Berdasarkan data di atas peneliti ingin melakukan penelitian tentang efektivitas terapi ice massage dan back massage terhadap perubahan intensitas nyeri pada penderita low back pain di Rumah Sakit Grandmed Lubuk Pakam Tahun 2020.

\section{METODE PENELITIAN}

Jenis penelitian ini adalah pre experiment (pra eksprimen) dengan model rancangan one group pre tes dan post test, karena penelitian ini di arahkan untuk melihat bagaimana efektivitas terapi Ice Massage dan Back Massage terhadap perubahan intensitas nyeri pada penderita Low Back Pain. Uji statisik yang digunakan untuk mengetahui ada tidaknya pengaruh terapi ice massage dan back massage yaitu dengan menggunakan uji Paired sample t-test. Penilaian nyeri diobservasi dengan menggunakan lembar observasi dimana masing masing terapi dinilai sebelum dan sesudah. Penelitian ini telah dilakukan di Rumah Sakit Grandmed Lubuk Pakam dengan jumlah pasien dari tahun 2018 berjumlah 45 dan pada tahun 2019 terdapat 59 pasien yang mengalami low back pain yaitu pasien yang dirawat di RS Grandmed Lubuk Pakam dengan diagnose low back pain. Penelitian dilakukan mulai bulan September 2019 - Februari 2020.

Teknik pengambilan sampel yang digunakan yaitu teknik Non Probability Sampling dengan pendekatan pengambilan sampel yaitu pendekatan purposive sampling dengan kriteria inklusi sampel yaitu pasien yang mengalami penyakit Low Back Pain dengan skala nyeri ringan (1-3), sedang (4-6) dan pasien yang tidak memiliki riwayat penyakit komplikasi. Sedangkan kriteria eksklusi yaitu pasien tidak sadar dan pasien yang mengalami penyakit kronis. Jumlah sampel yang digunakan yaiu sebanyak 20 dengan 10 responden untuk terapi ice massage dan 10 responden untuk terapi back massage.

\section{HASIL PENELITIAN}

Karakteristik Responden

\begin{tabular}{lcc}
\hline $\begin{array}{c}\text { Karakteristik } \\
\text { responden }\end{array}$ & $\begin{array}{c}\text { Frekuen } \\
\text { si }\end{array}$ & $\begin{array}{c}\text { Persentas } \\
\text { e (\%) }\end{array}$ \\
\hline Umur & 5 & 25 \\
< 40 Tahun & 15 & 75 \\
>40 Tahun & & \\
Jenis Kelamin & s8 & 40 \\
Laki - laki & 12 & 60 \\
Perempuan & & \\
Pendidkan & 3 & 15 \\
SMP & 11 & 55 \\
SMA & 4 & 20 \\
Diploma & 2 & 10 \\
Sarjana & & \\
Lama Penyakit & 7 & 35 \\
< 1 Bulan & 13 & 65 \\
>1 Bulan & & \\
Pekerjaan & 3 & 15 \\
IbuRumahTang & & \\
ga & 3 & 15 \\
Wiraswasta & 6 & 30 \\
Petani & 20 \\
Karyawan & 4 & 20 \\
PNS & 4 & \\
\hline & &
\end{tabular}

Berdasarkan table diatas dapat dilihat bahwa distribusi karakteristik responden berdasarkan umur diperoleh hasil frekuensi terbanyak adalah responden dengan umur> 40 tahun 
sebanyak 15 pasien (75\%). Berdasarkan jenis kelamin diperoleh hasil frekuensi terbanyak adalah responden dengan jenis kelamin perempuan 12 pasien (60\%). Berdasarkan pendidikan diperoleh hasil frekuensi terbanyak adalah responden dengan pendidikan SMA 11 pasien (55\%).Berdasarkan lama penyakit yang di derita pasien diperolehhasilfrekuensiterbanyak adalah lama penyakit $>1$ bulan 13 pasien $(65 \%)$. Sedangkan berdasarkan pekerjaan diperoleh hasil frekuensi terbanyak adalah pekerjaan petani responden 6 pasien (30\%).

\section{ANALISA UNIVARIAT}

\section{Intesitas nyeri sebelum dan sesudah dilakukan tindakan ice massage}

Tabel 4.2. Tingkat Intensitas Nyeri Sebelum Dilakukan Terapi Ice Massage Terhadap Penderita Low Back Pain di RS Grandmed Lubuk Pakam Tahun 2020.

\begin{tabular}{llll}
\hline $\begin{array}{l}\text { Tindakan } \\
\text { ice } \\
\text { massage }\end{array}$ & $\begin{array}{c}\text { Intensitas } \\
\text { Nyeri }\end{array}$ & $\mathbf{N}$ & $\mathbf{\%}$ \\
\hline Sebelum & Nyeri Ringan & 2 & 20,0 \\
& Nyeri Sedang & 8 & 80,0 \\
Sesudah & Tidak Nyeri & 2 & 20,0 \\
& Nyeri Ringan & 8 & 80,0 \\
\hline
\end{tabular}

Pada tabel 4.2 di atas menunjukkan bahwa mayoritas pasien sebelum dilakukan ice massage mengalami intensitas nyeri sedang yaitu sebanyak $8(80 \%)$ dan mayoritas pasien mengalami nyeri ringan setelah dilakukan ice massage yaitu sebanyak 8 orang ( $80 \%)$.

Intesitas nyeri sesudah dilakukan tindakan ice massage dan back massage
Tabel 4.3 Tingkat Intensitas Nyeri Sebelum dan Sesudah Dilakukan Terapi Back Massage Terhadap Penderita Low Back Pain Di RS Grandmed Lubuk Pakam Tahun 2020.

\begin{tabular}{llll}
\hline $\begin{array}{c}\text { Tindakan } \\
\text { Back } \\
\text { massage }\end{array}$ & $\begin{array}{c}\text { Intensitas } \\
\text { Nyeri }\end{array}$ & N & \% \\
\hline Sebelum & Nyeri Ringan & 1 & 10,0 \\
& Nyeri Sedang & 9 & 90,0 \\
Sesudah & Tidak Nyeri & 3 & 30,0 \\
& Nyeri Ringan & 7 & 70,0 \\
\hline
\end{tabular}

Pada tabel 4.3 di atas menunjukkan bahwa mayoritas pasien sebelum dilakukan back massage mengalami intensitas nyeri sedang yaitu sebanyak 9 orang (80 \%) dan mayoritas pasien mengalami nyeri ringan setelah dilakukan back massage yaitu sebanyak 7 orang (70\%).

\section{Analisa Bivariat}

Tabel 4.6 Hasil Analisis Efektivitas Terapi Ice Massage Terhadap Perubahan Intensitas Nyeri pada Penderita Low Back Pain di Rumah Sakit Grandmed Lubuk Pakam Tahun 2020.

\begin{tabular}{|c|c|c|c|c|c|c|}
\hline \multirow{3}{*}{$\begin{array}{c}\text { Nye } \\
\text { ri }\end{array}$} & \multicolumn{5}{|c|}{ Paired Test } & \multirow{3}{*}{$\begin{array}{c}\text { pValu } \\
e\end{array}$} \\
\hline & \multirow[t]{2}{*}{$\mathrm{N}$} & \multirow[t]{2}{*}{ Mean } & \multirow{2}{*}{$\begin{array}{l}\text { Stand } \\
\text { ar } \\
\text { Devia } \\
\text { si } \\
\end{array}$} & \multicolumn{2}{|c|}{$\begin{array}{c}95 \% \\
\text { Interval } \\
\text { Confidence }\end{array}$} & \\
\hline & & & & $\begin{array}{c}\text { Uppe } \\
\text { r }\end{array}$ & Lower & \\
\hline $\begin{array}{l}\text { Pre } \\
\text { test } \\
\text { Post } \\
\text { test }\end{array}$ & $\begin{array}{l}1 \\
0\end{array}$ & 3,4 & 0,516 & 3,769 & 3,031 & 0,002 \\
\hline
\end{tabular}

Pada tabel 4.6 menunjukkan bahwa rata-rata intensitas nyeri 3,40 dan standar deviasi (SD) $=0,516$. Hasil Uji statistic didapatkan nilai $p=0,002 \leq$ $\mathrm{a}=0,05$ maka dapat disimpulkan bahwa ada Efektivitas Terapi Ice Massage Terhadap Perubahan Intensitas Nyeri pada Penderita Low Back Pain. 
Tabel 4.7 Hasil Analisis Efektivitas Terapi Back Massage Terhadap Perubahan Intensitas Nyeri pada Penderita Low Back Pain di Rumah Sakit Grandmed Lubuk Pakam Tahun 2020.

\begin{tabular}{lcccccc}
\hline & \multicolumn{5}{c}{ Paired Test } \\
\cline { 2 - 5 } Nyeri & $\mathrm{n}$ & Mean $\begin{array}{c}\text { Stand } \\
\text { ar } \\
\text { Devia } \\
\text { si }\end{array}$ & $\begin{array}{c}\text { 95\% } \\
\text { Interval } \\
\text { Confidence }\end{array}$ & pValue \\
\cline { 2 - 5 } & \multicolumn{5}{c}{ Upper } & Lower \\
\hline $\begin{array}{c}\text { Pre } \\
\text { test } \\
\begin{array}{c}\text { Post } \\
\text { test }\end{array}\end{array}$ & 10 & 3,60 & 0,843 & 4,203 & 2,997 & 0,001 \\
\hline
\end{tabular}

Pada tabel 4.7 menunjukkan bahwa rata-rata intensitas nyeri 3,60 dengan standar deviasi $(S D)=0,843$. Hasil $U j i$ statistik didapatkan nilai $\mathrm{p}=0,001 \leq$ $\mathrm{a}=0,05$ maka dapat disimpulkan bahwa ada pengaruh Terapi Back Massage Terhadap Perubahan Intensitas Nyeri pada Penderita Low Back Pain

Table 4.8 Perbedaan Rata - rata antara Terapi Ice Massage dengan Terapi Back Massage Terhadap Perubahan Intensitas Nyeri pada Penderita Low Back Pain di Rumah Sakit Grandmed Lubuk Pakam Tahun 2020.

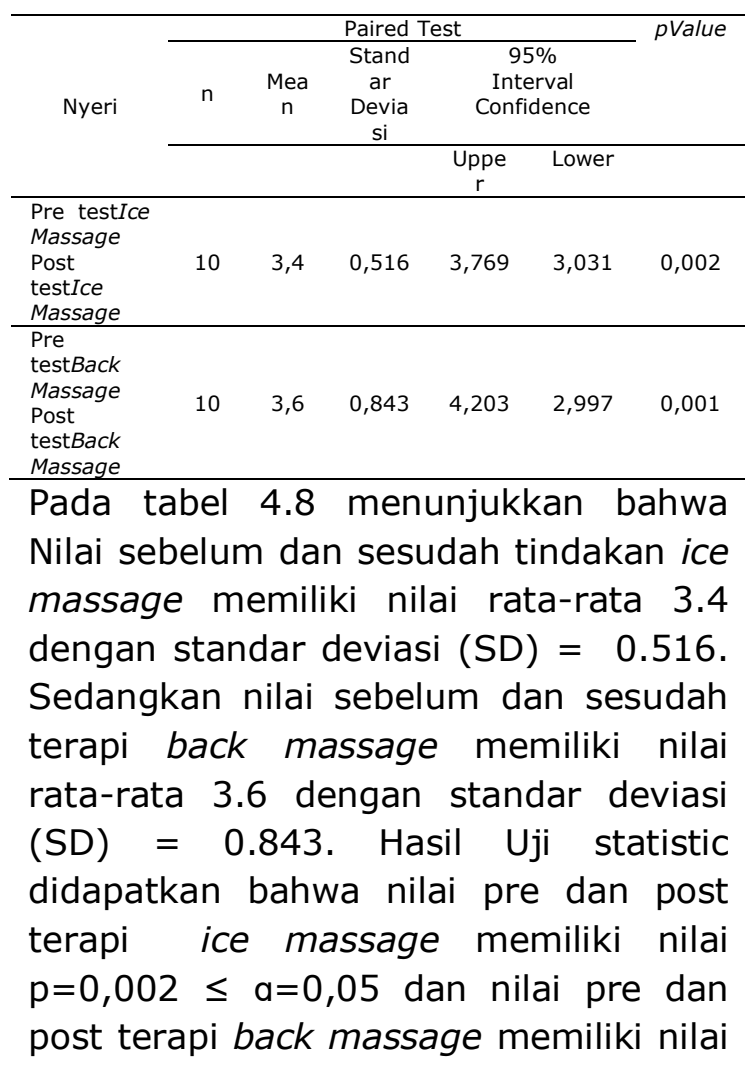

$p=0,00 \leq a=0,05$ maka dapat disimpulkan bahwa terapi back massage lebih efektif dari pada ice massage.

\section{PEMBAhASAN \\ Efektifitas terapi ice massagepada pasien low backpain}

Hasil penelitian rata-rata skala nyeri pada pasien Low Back Pain sebelum dilakukan terapi dinginIce Massage sebesar 3,4 Rata-rata skala nyeri pada pasien Low Back Pain sesudah dilakukan terapi Ice Massage sebesar 0,90 .Dengan menggunakan ujistatistik Paired Sample T-Test diperoleh nilai $p=0,001 \leq a$ 0,05. Dengan demikian penelitian ini menemukanbahwa ada efektivitas pemberian terapi Ice Massage terhadap intensitas nyeri pada pasien Low Back Pain Di Rumah Sakit Grandmed Lubuk Pakam Tahun 2020.

Hasil penelitian sesuai dengan penelitian oleh Eva Nurlis (2012) bahwa ada pengaruh terapi dinginice massage terhadap perubahan intensitas nyeri pada penderita low back pain. Kompres dingin dapat menurunkan nyeri pada pasien. Kompres dingin mempunyai beberapa keuntungan antara lain menimbulkan efek local analgesik, menurunkan inflamsi, meningkatkan ambang batas reseptor nyeri untuk kemudian menurunkan nyeri. Kompres dingin yang digunakan untuk mengurangi rasa nyeri ini diterapkan selama kurang lebih 20 menit, karena pemaparan dingin yang terlalu lama akan meyebabkan injuri pada jaringan (Bimariotejo, 2015).

\section{Efektifitas terapi back massage pada pasien low backpain}

Hasil penelitian rata-rata skala nyeri pada pasien Low Back Pain sebelum dilakukan terapi dinginBack Massage sebesar 3,600 Rata-rata skala nyeri pada pasien Low Back Pain sesudah 
dilakukan terapi Back Massage sebesar 0,80 . Dengan menggunakan uji statistik Paired Sample T-Test diperoleh nilai $p=0,001 \leq a \quad 0,05$. Dengan demikian penelitian ini menemukan bahwa ada efektivitas pemberian terapi Back Massage terhadap intensitas nyeri pada pasien Low Back Pain Di Rumah Sakit Grandmed Lubuk Pakam Tahun 2020.

Hasil penelitian ini sesuai dengan penelitian DewiKusuma (2017) bahwa ada pengaruh Back Massage terhadap tingkat nyeri low back pain pada kelompok Tani Semangka Mertha Abadi di Desa Yeh Sumbul.

Massage punggung dapat menyebabkan timbulnya mekanisme penutupan terhadap impuls nyeri saat melakukan gosokan penggung pasien dengan lembut. Pesan yang dihasilkan akan menstimulasi mekanoreseptor. Mengusap kulit klien secara perlahan dan berirama dengan gerakansirkular dengan kecepatan 60 kali usapan per menit selama 3-5 menit (Potter \& Perry, 2015).

\section{PENUTUP}

\section{Kesimpulan}

Berdasarkan uji statistik dan pembahasan tersebut diatasbahwa dapat disimpulkan bahwa ada efektivitas terapi Ice Massage dan Back Massage terhadap perubahan intensitas nyeri pada penderita Low Back Pain di Rumah Sakit Grandmed Lubuk Pakam Tahun 2019 :

1. Tingkat intensitas nyeri pada pasien Low Back Pain sebelum dilakukan terapi Ice Massage dan Back Massage yaitu seluruh responden mengalami nyeri sedang sebanyak 8 orang $(80,0 \%)$.

2. Tingkat intensitas nyeri pada pasien Low Back Pain sesudah dilakukan terapi Ice Massage mayoritasresponden mengalami tidak nyeri sebanyak 2 orang $(20,0 \%)$ dan nyeri ringansebanyak 8 orang $(80,0 \%)$.

3. Tingkat intensitas nyeri pada pasien Low Back Pain sesudah dilakukan terapi Back Massage mayoritasresponden mengalami tidak nyeri sebanyak 3 orang $(30,0 \%)$ dan nyeri ringansebanyak 7 orang $(70,0 \%)$.

4. Ada efektivitas terapi Ice Massage dan terhadap tingkatintensitasnyeri pada pasien Low Back Pain. Berdasarkan hasiluji statistic diperoleh nilai $p \leq 0.05$ yaitu $\mathrm{p}=0.001$.

5. Ada efektivitas terapi Back Massage dan terhadap tingkatintensitas nyeri pada pasien Low Back Pain. Berdasarkan hasiluji statistic diperoleh nilai $p \leq 0.05$ yaitu $p=0.001$.

6. Dilakukan uji statistic efektivitas antara terapi ice massage dan back massage terhadap tingkat intensitas nyeri pada pasien low back pain, maka berdasarkan nilai pValue, terapi back massage paling efektif terhadap penurunan intensitas nyeri dengan yaitu dengan memiliki pValue $=0,001$ sedangkan terapi ice massage memiliki pValue $=0,002$

\section{Saran}

1. Bagi Perawat

Hasil penelitian ini dapat dijadikan sebagai informasi dalam mengatasi nyeri sehingga dapat diterapkan dalam asuhan keperawatan terutama pada masalah keperawatan medical bedah khususnya pasien Low Back Pain.

2. Bagi Pasien

Hasil penelitian inidiharapkan dapat dijadikan sebagai bahan informasi tentang terapi Ice Massage dan Back Massage secara ilmiah dan dapat menerapkan terapi Ice 
Massage dan Back Massage sebagai terapi non-farmakologis yang aman, efektif dan untuk menurunkan skala nyeri.

3. Bagi Rumah Sakit Grandmed

Hasil penelitian ini diharapkan dapat menjadi masukan atau informasi yang selanjutnya dalam pengembangan kualitas pelayanan khusus pada pasien Low Back Pain.

4. Bagi Institut Pendidikan

Sebagai bahan informasi atau refrensi bagi perpustakaan Institut Kesehatan MEDISTRA Lubuk Pakam untuk pemanfaatan datadata bagi mahasiswa/I dalam pengembangan program penelitian selanjutnya

5. Bagi Peneliti

Diharapakan dapat melanjutkan penelitian ini dengan memperhatikan kestabilan penggunaan balok es dan teknik usapan (massage) pada punggung pada batas yang ditentukan dan faktor-faktor lain yang dapat menyebabkan penurunan nyeri pada pasien Low Back Pain.

\section{DaftarPustaka}

American Osteopathic Association. 2013. AOA Clinical Practice Guidelines for Osteopathic Manipulative Treatment (OMT) for patients with Low back pain.

http://www.osteopathic.org. di akses tanggal 26 Februari.

Agency for Health Care Policy and Research (AHCPR).Panel on the Prediction and Prevention of Pressure Ulcers in Adults. (2001). Prevention of Pressure Ulcers: A patient's Guide. Washington, D.C.: Public Health Service, U.S Department of Health and Human Services.
Bimaariotejo.2015. Klasifikasi low Back Pain.http://bimaariotejo.wordp ress.com.di akses tanggal 15 Maret 2019.

Caldwell\&Hegner,

2015.AsistenKeperawatan:Suat uPendekatanProsesPerawatan.J akarta:EGC

Ester,

$M$, 2015.PedomanPerawatanPasie n.Jakarta:EGC

Ganong, W. F. 2009. Buku Ajar FisiologiKedokteran.Edisi 22. Jakarta: EGC.

Guyton, A. C., Hall, J. E., 2015. Buku Ajar

FisiologiKedokteran.Edisi12.Jak arta : EGC, 1022

Hidayat.2016.KebutuhanDasarManusia. SalembaMedika, Jakarta.

Idyan, Z. 2007. Hubungan Lama DudukSaatPerkuliahan Dengan KeluhanLow Back Pain.Skripsi. Surabaya: Fakultas dokteran Universitas Airlangga ovember 28, 2015.

http://www.distrodoc.com/2234 44-hubungan-lama-posisidudukterhadap-nyeri-punggungbawahKenworthy al. 2002.Buku AjarKeperawatan Medical Bedah. Jakarta: EGC

Kusyati. 2016. Ketrampilan Dan ProsedurLaboratoriumKeperaw atanDasar. Jakarta : EGC

Kozier, B. 2015.Fundamental of Nursing: Concept, Prosess and Practice. $7^{\text {th }}$ ed. Pearson Education Inc. New Jersey.

Lukman dan Ningsih, N. 2013.Asuhan Keperawatan pada Klien dengan Gangguna Sistem Muskuloskeletal.

SalembaMedika. Jakarta.

Long, Barbara C, 2016, PerawatanMedikalBedah, (Volume 2), Penerjemah: Karnaen, Adam, Olva, dkk, 
Bandung: Yayasan Alumni PendidikanKeperawatan

Mahadewa. 2009. Diagnosis dan tatalaksanakegawatdaruratant ulangbelakang. Jakarta: Sagungseto.

Maher, S., and Pellino. 2016. Low BackPainSyndroma. FA Davis Company 4(3): 113. Philadelpia.

Muhammad Al. Fadli. 2014. "Influence of Managerial Ownership, Debt Policy, Profitability, Firm Size and Free Cash Flow on Dividend Policy". Delhi Business Review, Vol.15, No.1

Munir. 2012. Analisis Nyeri PunggungBawah pada PekerjaBagian Final Packing dan Part Supply di PT.X Tahun 2012.Tesis: Fakultas Kesehatan Masyarakat program Keselamatan dan Kesehatan Kerja UI.

Nursalam. 2012. Konsep dan PenerapanMetodologi Penelitian IImuKeperawatan. Salemba, Medika.

PERDOSI. 2002. Nyeri neuropatik di daerah punggungbawah (low back pain)

:penuntunpenatalaksanaan nyeri punggungbawah. Yogyakarta : PERDOSSI.

Priharjo. 2009. Pemenuhan Aktifitas Istirahat Pasien. EGC, Jakarta.

Prasetyo. 2010. Konsep dan Proses KeperawatanNyeri.GrahaIImu, Yogyakarta.

Potter, P. A \& Perry, A.G. 2015.Buku Ajar Fundamental: Konsep, Proses dan Praktik. EGC. Jakarta.

Sastroasmoro, Sudigdo (2013). DasarDasarMetodologi Penelitian Klinis. Jakarta: SagungSeto.

Siswanto, Bejo. 2014. Indonesia

PendekatanAdministratif dan Operasional. Jakarta: BumiAksara

Shocker,M, 2015. Pengaruh Stimulus Kutaneua : Slow Stroke Back Massage Terhadap Intensitas Nyeri Osteoarthritis, 20 Agustus 2019. 